\title{
THE LAST OF THE JUST: AN INTRODUCTION
}

\author{
Michael Parsons*
}

\section{Abstract}

A conference about André Schwarz-Bart's book The Last of the Just considered it from the perspectives of literature, psychoanalysis and spirituality. This introductory article offers brief reflections from all three viewpoints. The book's structure seems problematic because of its mixture of genres. It shifts from traditional folk tales to a description of adolescent torment, to a searing account of the Nazi persecution. The article suggests that there is nonetheless an underlying literary coherence to the book. In therapeutic terms the article explores an ambiguity about whether the picture of Ernie Levy, the book's hero, as a Lamed Vav is to be taken at face value, or whether it represents the desperate attempt of a disturbed young man to shore up his internal image of himself. From a spiritual perspective, the article discusses what it can mean that this almost unbearably dark book is framed by the statement that 'God enjoys himself'. When a Just Man takes all the evil of the world into his heart, Ernie's grandfather tells him, something changes for God. What God enjoys may, in Schwarz-Bart's vision, be His own dependence on the Lamed Vav, for something that He alone cannot make happen without the existence of the Just Men whom He has created.

I would like to welcome everyone to our ninth Trialogue Conference, and to thank you all very much for coming. And I mean this in a special and heartfelt way.

We thought very hard about selecting The Last of the Just for this year's Trialogue Conference. In the books that the Trialogue has looked at over the years, the spiritual element has been drawn largely from the Christian tradition, and I suggested we try and move outside it this time round. We looked in various directions, and decided in the end to choose a book based in the Jewish tradition. Judaism has appeared before in the Trialogue. I remember the character of Mordecai Himmelfarb in Patrick White's Riders in the Chariot, the book which was my introduction to the Trialogue. But it has not been the primary focus in the way that, for example, a certain strand

* Michael Parsons is a Training Analyst of the British Psychoanalytical Society and a member of the French Psychoanalytic Association. He is the author of The Dove that Returns, The Dove that Vanishes: Paradox and Creativity in Psychoanalysis (Routledge, 2000) and of Living Psychoanalysis: From Theory to Experience (Routledge, 2014). 
of Christianity was central to Marilynne Robinson's books that we read last time.

One of the indications for me of a good 'Trialogue book' is when I find myself wanting to write all three of the papers about it! Certainly, The Last of the Just is fascinating from every one of our three perspectives. But I think twice about saying I would want to write about it. The prospect of confronting this book is frightening because of where we have to go in ourselves if we are to stay with it. When word began to get about that we were considering The Last of the Just for the Trialogue this year, some said they thought it would be a mistake; that the book was just too dark and unbearable. I know that people have in fact stayed away because of that. This is why I really do thank you for coming. And especially I thank our three speakers. For all of us, a real encounter with this book requires courage.

This seems right to me. We should not be put off books that are problematic, difficult, even painful. I think that in its low-profile way the Trialogue Conference has a significant function in the world. Artistic creativity, spirituality, and the kind of therapeutic understanding offered by psychoanalysis are essential strands in the well-being, not just of individuals, but of humanity in general. The interconnections between them form a kind of nodal point, it seems to me, that is important for the development of our culture and society. The Trialogue Conference, as an arena for considering specifically these interconnections, can have an unobtrusive but valuable part to play in that. And this must involve being able to confront darkness when we have to.

To start us thinking about how an artistic, a psychotherapeutic and a religious viewpoint can relate to each other, I would like to offer an idea or two about our book from each one of these. First, though, I want to lead us into our encounter with The Last of the Just through some music. If you look now in your envelope no. 1, ${ }^{1}$ you will find the text of a song in praise of Jerusalem: Yefe Nof, Beautiful City, Delight of the World. It was written by Judah Halevi, a Spanish rabbi and doctor who was one of the greatest of mediaeval Jewish poets. He lived from about 1075 to 1141 , so this poem was written maybe fifty years before the pogrom in York that our book begins with. The setting is a modern arrangement of music dating from the time when the poem was written. [At this point the song Yefe Nof was played. ${ }^{2}$ ]

Now here is another piece of music. You will find the text for this in envelope no. 2. [A CD was played of the cantata A Survivor From Warsaw, by Arnold Schoenberg. The text of the cantata, but not the name of the piece or composer, was given in the envelope.] That was written in 1947 by Arnold Schoenberg, and it is called A Survivor from Warsaw. These two pieces mark the beginning and the end of the book. But beyond that, I think there are specific ways in which they speak of Ernie Levy. 
Schoenberg came from a working-class Jewish family in Vienna. His father had a shoe shop. When he was twenty-four Schoenberg left the Jewish faith and became a Lutheran Christian. Jewish themes remained present in his work. He wrote a spoken drama called The Biblical Way, and he struggled for years with an oratorio called Jacob's Ladder and with his opera Moses and Aaron. He did not manage to complete either of these. So he was preoccupied with Jewish themes, but his relationship to his own Jewishness was evidently conflicted. At the beginning of the 1930s Schoenberg, by then world-famous, was teaching composition at the Berlin Academy of Arts. In March 1933 the president of the Academy announced that Jewish influences were to be purged, whereupon Schoenberg immediately left Berlin - for Paris. He stayed in France for six months before leaving for the United States, where he spent his remaining years. In France he composed no new music. But what he did do was reconvert to Judaism. The certificate showing this is still extant, and it is interesting that one of his witnesses was Marc Chagall. You can see a copy of the certificate in our exhibition.

Schoenberg, in escaping from Europe, did what Ernie Levy's family did not do. In other ways, though, his journey seems curiously parallel to Ernie's, with its struggle to discover what his vocation as a Jew really means to him. On the one hand Schoenberg had to confront practically the appalling events that were unfolding. But when we hear, in A Survivor from Warsaw, of 'the old prayer that had been neglected for so many years - the forgotten creed!', followed by the triumphant reaffirmation of the Shema Yisrael, it is hard not to hear this as Schoenberg's perhaps less conscious description of his inner journey also, with its rejection of an identity and the rediscovery of it.

What links this to Ernie for me is a thought that Ernie has when he comes back to the garret in the Marais to find that the four old men, the last survivors of the Paris Association of the Elders of Zemyock, have been taken away. He thinks about dying heroically in some exploit of resistance, and then tells himself that 'for him it would have been a luxurious death. He had no wish to singularise himself, or detach himself from the humble procession of the Jewish people' (341). ${ }^{3}$

In the original French text, the word translated as 'procession' is 'cortège'. Schwarz-Bart's use of language here is subtle. In French 'cortège' does not, like the English 'cortege', have the primary meaning of a funeral procession. It means a group of people following someone as a mark of ceremonial honour and respect for that person: courtiers following a monarch, academics processing after their vice-chancellor. As one particular example of this, the word takes on a secondary, but only a secondary, meaning of a funeral procession following a coffin. The notion of the Jewish people, and the Just Men in particular, as a procession of honour that turns into a funeral procession is exactly what this book is about. 
This may help us to understand something about the book's structure. From a literary point of view the mixture of styles and genres seems problematic. The first few chapters are a series of folk tales about mysterious wise men and how they designate their successors. This is a distinct and recognizable kind of story. We think of Martin Buber's Tales of the Hasidim (Schocken Books, New York 1947). More distant cousins are Obi-Wan Kenobi and Luke Skywalker (in the Star Wars film series). Whatever our view of it - and I know that not everybody does enjoy this part of the book - we know the genre we are in. But then suddenly we are in the middle of an early twentieth century Bildungsroman, focusing on the emotional stress of an adolescent in a problem-ridden family, trying to discover how he wants to live his life: a sort of Jewish Sons and Lovers. And this shifts seamlessly into a searing historical documentary that becomes more and more unbearable, culminating in the Holocaust. What kind of book is this? Does this mixture of genres not pull it apart and destroy its literary coherence?

Schwarz-Bart is well aware of what he is doing. In the opening paragraph he states: 'The biography of my friend Ernie Levy could easily be set in the second quarter of the twentieth century. But the true history of Ernie Levy begins much earlier, toward the year one thousand of our era, in the old Anglican city of York. More precisely, on the $11^{\text {th }}$ of March, 1185.' SchwarzBart is saying: 'I could have written a novel of Nazism and the Holocaust. But I haven't. The point of this book is the continuity between 1185 and 1942 . That continuity transcends the differences along the way.'

The two pieces of music I played are as far apart from each other musically as the book's opening and closing chapters are in literary terms. But I played them, not for their differences, but for how they encompass the book. The continuity between them captures the linearity of generations from which neither Schoenberg nor Ernie Levy wanted to detach himself. If we think of the book as a cortège in the French sense, an honourable parade of celebration, with life present in all its variety, which is gradually transformed into a cortège as funeral procession, focusing down more and more on the coffin leading the way, then I think the transformations in the structure of the book begin to make sense.

Schwarz-Bart does another thing at the beginning of the book which is remarkable psychologically. Solomon Levy has his vision of the Eternal telling him that in every generation of his family there will be a Lamed Vav, of whom he is the first. The next paragraph begins: 'Authentic or mistaken, the vision of Solomon Levy arouses general interest' (6). 'Authentic or mistaken' ... Schwarz-Bart plants the question, here at the outset, of whether we are to believe the story which is the core of the whole book. He pulls the rug out when we have barely stepped onto it! And the original French is again worth noting. 'Authentic or mistaken' is a translation of 'Véridique ou trompeuse'. A 
more precise rendering would be 'Truthful or deceitful, the vision of Solomon Levy .... This emphasizes the vision as a communication, which may or may not be trustworthy. As readers we also have to decide whether to trust the story we are being told. In the book, that question lies dormant until old Mordecai, Ernie's grandfather, starts telling him the history of the Just Men and not just telling him, but reading it to him from a book, like the one we are reading. The child Ernie asks out loud 'if that all these stories are true?' (140). Are they véridiques ou trompeuses? Ernie's father Benjamin laughs in shock, his mother Judith 'seems to swell with fury', and his grandfather never reads to him from the book again.

So when Ernie becomes a Just Man, is this truth or a deception? You will remember that when the Nazi mob attacks the Jews at the synagogue and the child Ernie confronts their leader, Mordecai has a 'revelation' about Ernie, and tells him 'the prodigious history of the Levys from beginning to end'. There is a 'disquieting gleam' in Ernie's eye when he learns that the last Just Man died without designating a successor (178). Ernie deliberately resolves to fill the vacancy. He asks his grandfather 'What is a Just Man supposed to do in his life?' Mordecai is seized with a terrible trembling, sensing perhaps that something is going wrong, and explains that a Just Man does not set out to do anything. He simply is. Nonetheless, as soon as his grandfather had gone, Ernie 'seriously undertook the dream of his own martyrdom'. He has a vision in which he solemnly announces to Mrs Tuszynski that he is a Lamed Vav; and he confronts a group of Nazi-like crusader knights, making use of his secret Lamed Vav voice, which is rolling and magisterial. The knights' leader is the grocer from the Friedrichstrasse, whose daughter Ernie was falsely accused of molesting. Ernie incites the grocer to kill him. The grocer strikes him, Ernie rehallucinates the blow by the synagogue and, 'at last making up his mind to die, he stretched out romantically near the cupboard'. But 'the figure of his executioner' (181) disintegrates suddenly and disappears as his mother opens the door and the light comes on.

When his mother and grandmother leave him alone, he systematically thinks through all the tortures suffered by the Just Men his grandfather has been telling him about. 'Perhaps God would grant him the strength to suffer an authentic martyrdom. Yes, if he hardened his body, perhaps he would be ready, when the day came, to offer it heroically to the holocaust'. To prepare himself for his fate as a Just Man, Ernie deliberately burns his own hand, and does himself an extremely serious injury (177-184).

What is going on here? Is this a true Lamed Vav discovering his vocation? Or is Ernie a disturbed, self-harming adolescent in a problem family, who tries to be a saviour to his family through, in psychoanalytic language, narcissistic identification with an idealized self-object: the figure of the Just Man? We could take this further. When Ilse betrays Ernie's love by letting Hans 
Schliemann beat him up, 'a wild animal rushed up his throat, and he bayed for the first time'. He bites Hans ferociously in the leg and hand and stands 'growling in his throat, like a dog' (252). When the fight is over and Ilse has left with Hans and the others, Ernie, now at the river, has an experience of total emptiness. Then comes his horrifying massacre of the insects - Ernie's murder of himself as a Just Man of the Flies - and his final thought: 'I was not a Just Man ... I was nothing' (260). Then this despairing adolescent goes home and makes a very nearly successful suicide attempt. After Kristallnacht the Levys move to France and Ernie tries again to save his family, this time by joining the French army so that he can give them certificates showing they are related to a serving French soldier. With the defeat of the army and the capitulation of France, Ernie's attempts to be a saviour have collapsed and he finally suffers a psychotic breakdown. No longer feeling like a dog, he comes to believe he $i s$ a dog and tries to live as one.

Ernie is continually uncertain about the authenticity of his identity as a Just Man. When he has insisted on being admitted to the detention camp he makes his ablutions, and the doorkeeper of the bath house appreciates Ernie's saying he will remember him. He says to Ernie in turn, 'Mazel Tov!'. As he does so, 'two stars of David illuminate his eyes and Ernie knows that the doorman is a Just Man. So, he thinks, my ancestors are rejoicing with me, and I deduce from that that I am the just heir of the Just Men' (369). Ernie still, even at this stage, needs to find ways of reassuring himself.

Am I being unfair to Ernie in hearing him as romanticizing the role of a Just Man, and always trying to shore up his belief that he is one, out of his emotional need to be a saviour and hero? Is this what Schwarz-Barth is showing us, or should we take Ernie's story at face value, as we have done the stories of his predecessors down the ages? When Ernie runs away to be the Just Man of the Flies and is brought back by the peasant, Mordecai says to him that if he were a true Just Man, 'things would certainly not have come to pass this way' (216). Yet when Ernie recovers from being a dog and comes to live in the Marais, the president of the Elders of Zemyock remembers that Mordecai used to say he was certain his grandson 'would be called upon to become a Just Man. Not a Just Man of the Levys, but a true Unknown Just, an Inconsolable, one of those whom God dares not even caress with his little finger' (335). I may raise my therapeutic eyebrows when little Ernie almost destroys his own hand because he is training himself 'to offer [his body] heroically to the holocaust' (183), but in the end this is exactly what he does. And it is heroic. All the same, the picture of an inwardly fragile and damaged character, struggling against madness by identification with an idealized self, seems to me well grounded in the text, and psychologically coherent and persuasive. 
Maybe both are true. At the very end of the book, when the Jews are being herded into the gas chamber, Ernie is at last unequivocally named as a Just Man (406).

'O God', the Just Man Ernie Levy said to himself, as the blood of pity streamed from his eyes again, 'O Lord, we went forth like this thousands of years ago. We walked across arid deserts, through the Red Sea of blood, in a deluge of salt and bitter tears. We are very old. We are still walking. Oh, we would like to arrive at last!'

Maybe the book is saying that a Lamed Vav is bound to find madness not only in the world around him, but in his inner world as well, and that struggling with his own madness is a condition of his existence as a Lamed Vav.

I have been asking what Schwarz-Bart is up to, both in literary and psychological terms. Now I want to ask what God is up to in this book. We may remember that Chaim Levy, who knew the Baal Shem Tov and was called the Dancer of God until he lost his legs, refused until the end of his life to name any of his five sons as his successor. On his deathbed he said that God had revealed to him that his youngest son, the deformed, outcast idiot known as Brother Animal, was the next Just Man. "And laughing again in delight, old Chaim choked, gasped, exhaled a thin sigh: "Do you know? God enjoys himself', and died' (32).

Maybe God does enjoy a good joke at the expense of conventional prejudice; but the remark carries more weight than that. When Ernie Levy lives as a dog in Marseille, he becomes another 'Brother Animal'. SchwarzBart even points up the link by putting a dog in the story of the first Brother Animal. When he is obliged, on his deathbed, to designate his successor, Brother Animal says it is his nephew Joshua: 'You know, the one who has my yellow dog?' (35). Apparently it took Schwarz-Bart eleven years, writing this book, to get it the way he wanted, so I doubt if there is much in it that is accidental. This statement that God enjoys Himself comes from early on in the book. It is certainly no accident that Schwarz-Bart repeats the identical words near the end. When Ernie comes back from being a dog and the four Elders of Zemyock recognize who he is, the president looks for his grandfather's entry in the register. As he puts Ernie's name in the book next to Mordecai's he says, in the English translation, 'Do you know? God amuses himself?' (339). The translator has missed the repetition. He puts 'enjoys himself' in one place and 'amuses himself' in the other. But in the original French the phrases are identical. Schwarz-Bart frames the book with the idea that God enjoys Himself.

If God enjoys making Brother Animal a Just Man, and if Ernie is also 'Brother Animal' and God enjoys Ernie's name finding its way into the register of the Elders of Zemyock, is it Ernie's existence as a Lamed Vav 
that is a source of enjoyment for God? What is special and unique about a Lamed Vav is the quality of his suffering. So does God enjoy the suffering of mankind? That seems altogether wrong, and in a book about the Holocaust even to mention the idea might feel intolerable. The point about a Lamed Vav, though, is not simply that he suffers, but that he is a container for the suffering of others. 'The Lamed-Waf are the hearts of the world multiplied, into which all our griefs are poured, as into one receptacle' (5). The thought I draw from these passages is that the God portrayed in this book takes delight in a particular aspect of His creation: the fact that one person is able to take on themselves the suffering of another person.

We learn quite a lot in the book about how this works. In the first place it is not just an incidental feature of creation, but an essential aspect of it. When Benjamin discovers that his employer, Mr Goldfaden, does not believe in God, the question that terrifies him is 'But then, where does all the suffering go?' 'And seeing again Mr. Goldfaden's hopeless expression, he cried out in a sob that rippled through the darkness of the workshop: It gets lost, oh my God, it gets lost!' (74). The young Galician whom Benjamin befriends in Berlin hides in a well when his village is attacked. After the pogrom he climbs out and everybody has been murdered. He is alone. He buries all the bodies, saying the funeral prayers over every one. It takes eight days, and nobody comes. At this point the Galician throws rocks at the sky, and it shatters 'like a simple mirror, and its shards spread out on the ground! Then I said to myself, Yankel, if God is in little pieces, what can it mean to be a Jew?' (97). This is what happens when suffering has nowhere to go, and it gets lost. At the very beginning of the book, the generations of Just Men are promised because 'the solitary agony of Rabbi Yom Tov was unbearable to God' (6). The essential word here, to my mind, is 'solitary'. It was unbearable to God that the rabbi's suffering should have nowhere to go.

A person cannot decide for themselves to take on the suffering of others. Ernie's attempts as a child to take on the suffering of members of his family only go to show that he is not, or not yet at least, a Just Man. The Just Man at the time of the Zemyock pogrom tries to get himself martyred and is only mocked for it. This is not how it works, and some people perceive in the Just Man's survival 'a mysterious and terrifying irony' (84). As Mordecai tries to explain to Ernie, a Lamed Vav does not have to do anything. It is the nature of his being to act as a receptacle for the griefs of others. Ernie gets closer to what this might mean when he is lost in the fields and becomes a Just Man of the Flies (210). His own being slips into the being of the fly he has caught, letting him realize its terror, in a way that is quite different from his rather hungry attempts to get inside the beings of the members of his family and become their saviour. 
Here is another conversation between Ernie and his grandfather, which I think may be really the heart of the book. Ernie has confessed that he thought if he could die, it would mean his family would live (187).

Mordecai fell into a long meditation. 'But then,' he said at last in a very gentle voice, 'when I explained to you last night that the death of a Just Man changes nothing in the order of the world, didn't you understand what I meant?'

'That, no, I didn't understand.'

'All right, then, listen to me', Mordecai said after a little more reflection. 'Open both your ears: if a man suffers all alone, it is clear, his suffering remains with him. Right?'

'Right', Ernie said.

'But if another looks at him and says "How you suffer, brother Jew" ... what happens then?'

'I understand that too', Ernie said politely. 'He takes the suffering of his friend into his own eyes.'

Mordecai says to Ernie, suppose someone is blind, and deaf, and cannot touch his friend either: 'Do you believe then that he can take in his pain?'

'Maybe he could sense it', Ernie said cautiously.

Mordecai went into ecstasies: 'You've said it, my love, that is exactly what the Just Man does! He senses all the evil on the earth, and he takes it into his heart!'

With a finger against the corner of his mouth, Ernie followed the course of a thought. He sighed: 'But what good does it do to sense it, if nothing is changed?'

'It changes for God, don't you see?'

And as the child frowned sceptically, Mordecai suddenly became terribly thoughtful. 'That which is far off,' he murmured as if to himself, 'that which is deep, deep, who can reach it?'

This phrase, 'That which is far off, that which is deep, deep, who can reach it?', is given emphasis by being repeated twice in the next two pages, once again by Mordecai and once by Ernie, talking to Moritz.

Mordecai is overwhelmed, I think, by realizing that the Just Man changes something for God, in a way that God alone cannot make happen without the Just Man's existence. The Lamed Vav are part of God's creation, so His omnipotence is not compromised. Nevertheless, this capacity of God's creation to share suffering; not merely to sympathize, but for one part of it to take on the suffering of another part of it: this is a reflection of God's loving nature, but it is a statement which God cannot make for Himself. I suggest that what the God of The Last of the Just enjoys is knowing that, omnipotent 
as $\mathrm{He}$ is, $\mathrm{He}$ is also dependent in this way on the world $\mathrm{He}$ has chosen to create.

\section{Closing Remarks}

This discussion has been based purely on the text of The Last of the Just. I have touched on some literary, psychotherapeutic and spiritual questions that were raised for me by the experience of reading the book. There is a lot to say as well, of course, about the man who made the book: about who André Schwarz-Bart was, and what he was doing in writing this book, at a certain time in his life and a certain moment in history. There is much to consider too about that wider historical frame: what happened in France during the Second World War and in the years after it. I cannot touch on these things now, but I am sure that we are going to hear and discuss a lot about Schwarz-Bart himself and about the context of his book.

The music I played earlier, from the twelfth century and from 1947, related to that wider context. I am going to end with another piece of music which relates to it more powerfully and painfully still. You will find the text for this in envelope no. 3. Both musically, and historically, this is something extraordinary. One day in Auschwitz, in 1941, sixteen hundred Jews were about to be executed. A cantor called Shlomo Katz asked if, while the Jews were digging their own graves, he could sing the El Male Rachamim, the prayer chanted at funerals for the ascent of the soul to God. The Nazi officer in charge was so struck by Shlomo Katz' singing that he did not kill him, and in fact allowed him to escape from the camp. (The rest of the sixteen hundred were murdered nonetheless.) In 1950 Shlomo Katz recorded what he had sung in Auschwitz, changing the liturgical words to make the prayer a commemoration of all the Jews who died in the extermination camps.

This is that recording. [At this point El Male Rahamim was played. ${ }^{4}$ ]

\section{Notes}

1. Members of the audience were each given three envelopes, marked 1,2 and 3, to open during the talk.

2. From the two-CD set JERUSALEM. La Ville des deux Paix: La Paix céleste et la Paix terrestre by Jordi Savall (Alia Vox AVSA9863 A+B), Disc 1, Track 23.

3. Page references are to The Last of the Just, trans. Stephen Becker, London 1961.

4. From JERUSALEM by Savall, Disc 2, Track 12. 